\title{
Long-term estrogen exposure of whitefish Coregonus lavaretus induces intersex but not Lake Thun-typical gonad malformations
}

\author{
S. Kipfer, H. Segner ${ }^{*}$, M. Wenger, T. Wahli, D. Bernet \\ Centre for Fish and Wildlife Health, University of Bern, Laenggass-Strasse 122, PO Box 8466, 3001 Bern, Switzerland
}

\begin{abstract}
A high prevalence of gonad morphological variations has been observed in whitefish Coregonus lavaretus from Lake Thun (Switzerland). To clarify the role of endocrine disruption as a possible cause of the gonad alterations, whitefish were reared in a long-term laboratory experiment under exposure to $17 \beta$-estradiol (E2). Fish were fed from first-feeding until $3 \mathrm{yr}$ of age at a daily rate

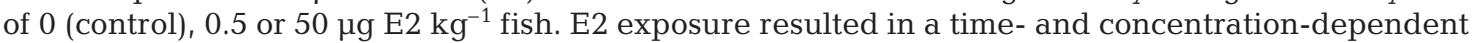
increase of prevalence and intensity of intersex gonads, i.e. gonads that macroscopically appeared as either testis or ovary but microscopically contained both male and female germ cells. Four types of intersex could be distinguished: Types 1 and 2 were composed of mainly male tissue, with Type 1 containing single oocytes and Type 2 displaying an ovary-like lamellar structure of the tissue. In Type 3 , an increased percentage of the tissue was occupied by female germ cells, while in Type 4, the majority of the gonad tissue consisted of female germ cells. Chronic E2 exposure additionally resulted in a concentration-dependent shift of the sex ratio towards females, a reduced condition factor, retarded gonad growth together with delayed maturation of germ cells, and elevated levels of hepatic vitellogenin mRNA. However, Lake Thun-typical alterations of gonad morphology were not induced by chronic E2 exposure. The results provide evidence that estrogen-active compounds unlikely play a role in the etiology of gonad malformations in Lake Thun whitefish.
\end{abstract}

KEY WORDS: Estrogen · Whitefish · Coregous lavaretus · Gonad morphology · Sex differentiation · Intersex $\cdot$ Vitellogenin $\cdot$ Endocrine disruption

\section{INTRODUCTION}

In the year 2000, commercial fishermen reported the occurrence of morphologically altered gonads in whitefish Coregonus lavaretus from Lake Thun (Switzerland). An initial survey showed that $35 \%$ of the examined whitefish in Lake Thun had gonad alterations deviating from normal morphology (Bernet et al. 2004). Macroscopic and microscopic examinations revealed several types of alterations: adhesions/ fusions to the peritoneal wall and the lateral trunk musculature, asymmetry, aplasia/atrophy, compartmentations, constrictions and intersex. More recent investigations have shown that some of the gonad morphological alteration types are also present in corego- nids of 2 neighboring lakes. Constricted and asymmetrical gonads were reported in comparable frequencies in whitefish from Lakes Brienz and Biel (Bittner et al. in press). Similar observations were made from Lakes Neuchâtel and Lucerne of another watershed (D. Bernet unpubl. data). This indicates that these traits largely represent a natural variation in gonad morphology of whitefish. However, the situation in Lake Thun is unique due to the enhanced overall prevalence of malformations and the significantly higher occurrence of 4 types of gonad alterations, i.e. intersex gonads, compartmentations, fusions and aplasia/ atrophy (Bittner et al. in press).

Until now, the causes of the gonad alterations are not clear. As Lake Thun water is used as the source of 
drinking water for $\sim 400000$ inhabitants of the area, a possible impact of environmental pollution is of particular public concern. In addition, whitefish is a frequently eaten fish and chemical contamination could therefore pose a risk to consumers. Relevant to human health and the health and development of the coregonid populations, it is thus important to clarify the causes of the gonad alterations.

Variations in gonad morphology of fish have been reported in a number of studies worldwide (Kinnison et al. 2000, Blazer 2002, Mikaelian et al. 2002). In fact, the morphology and differentiation of the gonads of fish are known to be susceptible to a variety of environmental factors such as temperature (Patino et al. 1996, Baroiller et al. 1999), parasites (Wiklund et al. 1996, Jobling \& Tyler 2003) and chemical substances (Kime 1995, Jobling et al. 1998). One environmental condition that has repeatedly been found to cause gonad alterations in fish is exposure to endocrine-disrupting compounds (EDCs) (Segner et al. 2003, Matozzo et al. 2007). Among the endocrine-active substances, chemicals that act as estrogen-receptor ligands and activate estrogen signaling pathways have received the most attention. These compounds include industrial chemicals (so-called xenoestrogens; e.g. certain alkylphenols or bisphenol A), phytoestrogens, as well as natural and synthetic estrogens (Jobling \& Tyler 2003, Sumpter \& Johnson 2005). Both field and laboratory studies have shown that exposure of developing fish to estrogenactive compounds can induce alterations in gonad morphology, including the development of hermaphroditic or intersex gonads, i.e. the presence of oocytes in testicular tissue (Gray \& Metcalfe 1997, Gray et al. 1999, Seki et al. 2002, Palace et al. 2006).

The aim of the present study is to evaluate whether exposure of developing coregonids to estrogen-active compounds would induce the specific Lake Thuntypical gonad malformations, i.e. intersex, gonad compartmentations and adhesions/fusions, and aplasia/ atrophy. We exposed whitefish to natural estrogen $17 \beta$-estradiol (E2) under laboratory conditions. A chronic exposure scenario starting from first feeding up to 3 yr of age was chosen, since this time span covers the period of gonad development in whitefish (D. Bernet unpubl. data). Fish and their gonads were macro- and microscopically examined. In addition, histopathological investigations of heart, kidney and liver tissues were made as E2 induced pathologies in these organs have also been described in other estrogen treated fish species (Folmar et al. 2001, Zaroogian et al. 2001, Palace et al. 2006, Zha et al. 2007). To assess the effectiveness of the dietary E2 administration, hepatic expression of vitellogenin (VTG) was measured, as this gene is under the direct control of the estrogen receptor pathway.

\section{MATERIALS AND METHODS}

Experimental design. Adult whitefish (central alpine Coregonus lavaretus) of the ecotype 'Albock' from Lake Thun were artificially stripped. The fertilized eggs and early larvae were reared in spring water in the government hatchery in Reutigen, Switzerland. At an age of $87 \mathrm{~d}$ post hatch (dph) on May 19, 2005, the fish were transferred to the Centre for Fish and Wildlife Health, University of Bern. They were divided into 3 groups of 145 ind. and acclimated in 2201 aquaria supplied with tap water for over 1 mo. On June 25, 2005 (122 dph), the experimental treatments were started and maintained until October 10, 2007 (960 dph). One group served as control and received a commercial feed (see below for feed types). The second and third groups (hereafter called 'low dose group' LD and 'high dose group' HD, respectively) were fed with the same feed but respectively enriched with 0.05 and $5 \mathrm{mg} \mathrm{E} 2 \mathrm{~kg}^{-1}$ feed. All groups were fed at $1 \%$ of body weight $\mathrm{d}^{-1}$. This resulted in a daily intake rate of $0.5 \mu \mathrm{g} \mathrm{E} 2 \mathrm{~kg}^{-1}$ fish (LD group) and $50 \mu \mathrm{g} \mathrm{E} 2 \mathrm{~kg}^{-1}$ fish (HD group). From 98 until $148 \mathrm{dph}$, all fish were fed AgloNorse 1 ( 0.3 to $0.6 \mathrm{~mm}$ grain size, EWOS). Thereafter until $220 \mathrm{dph}$, they received AgloNorse 2 (0.6 to $1.0 \mathrm{~mm}$ grain size, EWOS). From 221 until 390 dph, Hokovit Silvercup Superstarter 500 (Hokovit) was used as feed. Thereafter until the end of the experiment (960 dph), the treatment groups received pellets of 1.2 to $1.6 \mathrm{~mm}$ size (Hokovit).

Addition of E2 (estradiol-2,4,16,16-D4; 95 to $97 \%$; DLM-2487-0; Cambridge Isotope Laboratories) to the diet was achieved by using the alcohol method of Guerrero (1975). Briefly, a stock solution of E2 was generated (50 $\mathrm{gg}$ E2 $\mathrm{ml}^{-1}$ ethanol) from which predefined quantities were obtained and added to $10 \mathrm{~g}$ of food: for the HD group, $1 \mathrm{ml}$ stock solution in $9 \mathrm{ml}$ ethanol, for the LD group, $0.01 \mathrm{ml}$ stock solution in $9.99 \mathrm{ml}$ ethanol, and for the control group, $10 \mathrm{ml}$ ethanol. These mixtures were then air dried for $24 \mathrm{~h}$ at $70^{\circ} \mathrm{C}$.

Effective E2 concentrations and estrogenicity of the fish feed were analysed using HPLC (LC/MS/MS) and yeast estrogen screen (YES) assay, respectively (R. Schönenberger \& A. Liedtke unpubl. data). E2 concentrations measured were below the detection limit (3.6 $\left.\mu \mathrm{g} \mathrm{E} 2 \mathrm{~kg}^{-1}\right)$ in the control feed and the LD group feed, and amounted to $3.5-3.8 \mathrm{mg} \mathrm{E} 2 \mathrm{~kg}^{-1}$ in the HD group feed (70 to $76 \%$ of the nominal concentration of $5 \mathrm{mg} \mathrm{E} 2 \mathrm{~kg}^{-1}$ ). The YES assay showed a low background level of $2.1 \times$ $10^{-10} \mathrm{M}$ E2 equivalents (EEQ) in control feed. This was 2fold lower than the level of the LD group feed $(4.3 \times$ $10^{-10} \mathrm{M}$ EEQ) and 6-fold lower than the YES activity of the HD group feed $\left(1.5 \times 10^{-10} \mathrm{M} E E Q\right)$.

Water temperature was measured daily to estimate the day degrees. The biomass of each group was calcu- 
lated monthly and the diet portion $\left(1 \% \mathrm{~kg}^{-1}\right.$ fish weight) readjusted.

Sampling. Fish were sampled at 14, 42, 77, 347 and 838 d of E2 exposure, corresponding to 136, 164, 191, 469 and $960 \mathrm{dph}$, respectively. For the first 3 samplings, 5 ind. from each group were taken (exceptions: LD group $(\mathrm{n}=6)$ after $42 \mathrm{~d}$ of exposure, and control group ( $\mathrm{n}=7$ ) and LD group $(\mathrm{n}=6)$ after $77 \mathrm{~d}$ of exposure). After $347 \mathrm{~d}$ of exposure, a high gas supersaturation of the water due to maintenance works of the urban water service in the vicinity led to an acute gas bubble disease in the fish, followed by heavy losses on that day. No negative influences of this incidence on the parameters tested were expected and could have been revealed. Therefore we decided not to exclude fish from this day in our study. All dead fish resulting from this incidence (C: $\mathrm{n}=70$; LD: $\mathrm{n}=81$; HD: $\mathrm{n}=42$ ) were included and analysed (sampling 4). Due to the losses, sample sizes in each group at the final sampling were (1) lower than planned and (2) differed between the different treatment groups (C: $\mathrm{n}=26$; LD: $\mathrm{n}=15$; HD: $\mathrm{n}=36$ ).

Fish were killed with an overdose of tricaine methanesulfonate (Finquel MS 222, Argent Chemical Laboratories), and afterwards measured and weighed. The condition index was calculated as condition factor $(\mathrm{CF})=100 \times$ weight $(\mathrm{g}) \times$ total length $(\mathrm{cm})^{-3}$. For histological investigations, fish up to a length of $7 \mathrm{~cm}$ were fixed in toto in $4 \%$ buffered formalin. In bigger fish, the gonads were dissected and macroscopically assessed for malformations according to the criteria of Bernet et al. (2004), i.e. the presence or absence of the following morphological traits was recorded: constriction, asymmetry, atrophy/aplasia, compartmentation, adhesion/fusion, and intersex. The gonads were preserved in buffered formalin. At the final sampling (838 $\mathrm{d}$ of exposure), the gonads were weighed for the calculation of the gonadosomatic index $(\mathrm{GSI})=100 \times$ gonad weight $(g) \times$ body weight $(g)^{-1}$. Liver tissue was dissected and preserved in RNAlater (Ambion) for VTG analysis. In addition to the gonads, liver, heart and kidney tissues were also preserved in buffered formalin.

Histology. Formalin fixed fish or gonads were paraffin-embedded, cut into $5 \mu \mathrm{m}$ thick sections and stained with haematoxylin-eosin according to standard procedures. The histological staging of the germ cells during gonad differentiation followed the descriptions of Patino \& Redding (2000) and van Aerle et al. (2004) for fathead minnow Pimephales promelas. Germ cells were classified into primordial germ cells (PGC) in juvenile fish, and into primary oocytes (PO), bouquet stage, chromatin-nucleolar stage $(\mathrm{CN})$, peri-nucleolar stage (PN), balbiani body stage (BB), cortical alveolus stage (CA), first occurrence of egg shells, vitellogenic (VO) and mature oocytes in female fish. In male fish, spermatogonia, spermatocytes, spermatids, spermatozoa, the occurrence of testis lobules, and the presence of the sperm duct in the testis strands were used for classification. Intersex gonads were classified into macroscopic and microscopic intersex. Macroscopic intersex gonads were further classified as 'mosaic gonad type' (Kinnison et al. 2000), also termed as 'multifocal distribution type' (Nolan et al. 2001), and 'lobular gonad type' (Kinnison et al. 2000) or 'focal distribution type' (Nolan et al. 2001). In mosaic intersex fish, ooyctes occur in testicular tissue or spermatogenic cells develop in ovarian tissue. The 'lobular gonad type' is characterized by confined areas of ovarian and testicular tissue along a gonad strand, often separated by connective tissue. Microscopic intersex gonads were classified macroscopically as either testis or ovary but microscopically contained both male and female germ cells. Microscopic intersex types were further distinguished into Types 1 to 4 . Type 1 is composed of mainly male tissue with single oocytes and Type 2 has ovary-like lamellae structure of the male tissue. In Type 3, the female parts are increased and male germ cells are mainly replaced by female germ cells in Type 4.

Germ cells of 1 section per individual from remaining fish (from the final sampling) that macroscopically showed the most developed ovaries or testes were quantified stereologically. This resulted in the following subset from the final sampling: $\operatorname{HD}$ group $\left(\mathrm{n}_{\text {males }}=1\right.$; $\left.\mathrm{n}_{\text {females }}=15\right)$, LD group $\left(\mathrm{n}_{\text {males }}=3 ; \mathrm{n}_{\text {females }}=5\right)$, control group $\left(\mathrm{n}_{\text {males }}=8 ; \mathrm{n}_{\text {females }}=7\right)$. Micrographs were taken using the $40 \times$ objective of a light microscope for testicular tissue and the $2.5 \times$ objective for ovarian tissue on randomly selected areas (Zeiss universal microscope with a $35 \mathrm{~mm}$ Nikon digital camera). A 9-field standardized grid with mesh lengths of $60 \mu \mathrm{m}$ for testicular tissue and $909 \mu \mathrm{m}$ for ovarian tissue was laid over every picture. Male germ cells and BB, CA, egg shell, $\mathrm{VO}$ and atresia stage in the ovaries of 4 nonadjacent fields were counted, including partially cut germ cells. The area of the 4 fields was $0.014 \mathrm{~mm}^{2}$ for testis and $3.305 \mathrm{~mm}^{2}$ for ovary sections.

Histopathology was performed on haematoxylineosin stained sections of liver, heart and kidney tissues.

Quantification of vitellogenin (VTG). A real-time RT-PCR was used for the relative quantification of VTG mRNA gene expression to assess effectiveness of the estrogen exposure on the fish.

RNA preparation: Total RNA was extracted from liver tissue of whitefish using trizol reagent (Invitrogen) according to the manufacturer's protocol. The extracted RNA was resuspended in RNA storage solution (Invitrogen). To remove traces of contaminating DNA, the RNA samples were treated with DNase (Ambion) before RT-PCR analysis. The concentration 
of the purified RNA was measured at 260 and $280 \mathrm{~nm}$ using a NanoDrop ND-1000 UV-vis spectrophotometer (NanoDrop Technologies).

Reverse transcription: Syntheses of cDNA were carried out in a $42 \mu \mathrm{l}$ reaction mixture containing RNase free water (Applied Biosytems), buffer, $500 \mu \mathrm{g} \mathrm{ml}^{-1}$ random primers, $40 \mathrm{U} \mathrm{\mu l}^{-1}$ RNase inhibitor, $10 \mathrm{mM}$ dNTPs and $200 \mathrm{U} \mathrm{\mu l}^{-1} \mathrm{M}$-MLV reverse transcriptase (Promega). To this $42 \mu \mathrm{l}$ reaction mixture, $1 \mu \mathrm{g}$ RNA was added. The cDNA synthesis was performed in a thermocycler (PTC-200 DNA Engine, MJ Research, BioConcept) under the following conditions: $25^{\circ} \mathrm{C}$ for $10 \mathrm{~min}, 42^{\circ} \mathrm{C}$ for $1 \mathrm{~h}$ and $94^{\circ} \mathrm{C}$ for $10 \mathrm{~min}$.

Primers and probe design for TaqMan real-time $R T$ PCR: Based on established VTG mRNA sequences from Onchorhynchus mykiss, Danio rerio, Cyprinus carpio and Fundulus heteroclitus, primers for Coregonus lavaretus for conventional RT-PCR were taken. Using a 1-step RT-PCR kit (Quiagen), the RT-PCR amplification of the target gene was performed, checked on agarose gel and sequenced as described by Burki et al. (2006). Based on the partial sequences of VTG as determined by sequencing, a primer and one internal fluorescent probe (Table 1) was designed using the primer express software (PE Biosystems). The internal probes were labeled at the $5^{\prime}$ end with the reporter dye 6-carboxyfluorescein and at the $3^{\prime}$ end with the quencher dye 6-carboxytetramethyl-rhodamine (Burki et al. 2006).

VTG real-time RT-PCR: Triplicates of $25 \mu \mathrm{l}$ reactions consisting of Master Mix (Applied Biosystems), $\mathrm{H}_{2} \mathrm{O}$, $2 \mu \mathrm{Mol}$ probe (Microsynth), $10 \mu \mathrm{Mol}$ of forward and reverse VTG-primer (Microsynth) and $2 \mu \mathrm{l}$ of cDNA template were combined using a 96-well plate. Real-time RT-PCRs were performed using a 7300 Real-Time PCR System (Applied Biosystems) in conjunction with the 7300 SDS software (Applied Biosystems). The thermal program used was as follows: Stage $1,50^{\circ} \mathrm{C}$ for $2 \mathrm{~min}$; Stage $2,95^{\circ} \mathrm{C}$ for $10 \mathrm{~min}$; and Stage 3, 45 repetitions of $15 \mathrm{~s}$ at $95^{\circ} \mathrm{C}$ and $1 \mathrm{~min}$ at $60^{\circ} \mathrm{C}$ (point of data collection).

18s RNA was measured as a reference gene according to the manufacturers protocol using a kit by Applied Biosystems.

Dilution curve of VTG mRNA: A dilution curve was generated by performing a 2-step, real-time RT-PCR on a 10-fold dilution series of the total extracted RNA containing VTG mRNA. To estimate the amplification efficiency of VTG mRNA and 18s RNA, dilution curves (10-fold dilution steps) of total hepatic RNA were prepared from a positive control sample (liver of mature female). The threshold cycle number ( $\mathrm{Ct}$ ) of the various dilutions were determined using 2-step real-time RTPCR for VTG and 18s RNA. From these Ct values, the slope of the dilution curve was determined. The slope of the VTG mRNA dilution curve was compared to that of the 18s RNA dilution curve. In addition, the slope of the 18s RNA dilution curve was compared to that of $18 \mathrm{~s}$ RNA specified by the manufacturer (Applied Biosystems application note, part no. 127AP05). No significant differences in efficiency between any of the amplifications were found.

Data analysis: Transcript abundance of VTG was normalized to the abundance of the 18s RNA and reported as number of VTG copies $(1000)^{-1}$ copies of 18s RNA (Garcia-Reyero et al. 2004).

Statistical analysis. Differences in intersex frequency among the groups were analyzed using Fisher's exact test. Group differences in both CF and GSI values were determined using the Kruskal-Wallis multiple comparison $Z$-value test. VTG values were log transformed and tested for normality. Pairwise comparisons of VTG values between groups, sampling time and normality/ abnormality of the gonads were performed using a GLM 2-way-ANOVA, where 'treatment group' and 'sampling date' or 'gonad morphology' were categorical independent variables, followed by a Tukey-Kramer multiple comparison test. Homoscedasticity and normality of the residuals of this model were checked using a multiple regression model since it was not possible to calculate the residuals with the GLM 2-wayANOVA function of the applied software. All statistical analyses were performed using NCSS 2001 (Number Cruncher Statistical Systems).

\section{RESULTS}

Initially, we report whether E2 treatment induced the Lake Thun-typical morphological gonad alterations in the experimental fish. Next, we describe further parameters of whitefish affected by E2 exposure including sex ratio and VTG levels.

Table 1. Coregonus lavaretus. Primers and probe for the TaqMan real-time reverse transcriptase-PCR of vitellogenin (VTG). $\mathrm{fw}=$ forward $; \mathrm{rv}=$ reverse $; \mathrm{bp}=$ base pairs

\begin{tabular}{|llc|}
\hline Primer/Probe & Sequence $\left(5^{\prime}-3^{\prime}\right)$ & PCR fragment length $(\mathrm{bp})$ \\
\hline VTG TaqMan fw & ATC AAG AAG ACA CAG AAC GTC TAT GAG $(27 \mathrm{bp})$ & \\
VTG TaqMan rv & CTG ATC ACA TAG TGG GTC TTG CA $(23 \mathrm{bp})$ & 177 \\
VTG TaqMan probe & CCC TGA GCT CCA GCC TCC TGC A $(22 \mathrm{bp})$ & \\
\hline
\end{tabular}




\section{Gonad morphological alterations in whitefish}

Gonad alterations reported in whitefish from Lake Thun include adhesions/fusions, asymmetry, atrophy, compartmentations, constrictions and intersex, both macroscopical and microscopical (Bernet et al. 2004). In chronically E2 exposed fish from the experiment, atrophic, constricted and intersex gonads were detected (Table 2). Macroscopically, gonad atrophy and gonad constrictions were observed both in controls and E2 treated fish (Table 2). The frequency of these 2 alterations did not show a dose-dependent response to E2 exposure: gonad atrophy was observed in $4.1,5.2$ and $1.6 \%$ of the females from the control, LD and HD groups, respectively. Males with atrophic gonad strands were only seen in the LD group $(7.7 \%)$ (Table 2). Constrictions of the gonads were present in $9.6 \%$ of the control males and in $2.6 \%$ of the LD males. In the HD treatment group, constrictions were present only in females, with a prevalence of $1.6 \%$. None of the other macroscopical gonad alterations observed in wild whitefish from Lake Thun were present (i.e. compartmentations, fusions or asymmetrical gonads). Also, no macroscopic intersex-one of the eye-catching morphological traits in whitefish from Lake Thunwas observed.

The only gonad alteration that showed a clear and dose-dependent relation to E2 feeding in our experiment was microscopical intersex. Long-term feeding of developing coregonids with E2 enriched diets resulted in a significant and dose-dependent increase in the number of fish showing intersex gonads (Fisher's exact test; $\mathrm{p}<0.05 ; \mathrm{n}_{\mathrm{C}}=113 ; \mathrm{n}_{\mathrm{LD}}=115 ; \mathrm{n}_{\mathrm{HD}}=90$ ). While only $1 \%$ of the fish in the control group had intersex gonads, the percentage of intersex gonads increased to 6.7 and $20.5 \%$ in the LD and HD groups, respectively (Table 2). The intersex gonads were all of the mosaic type, i.e. single oocytes or oocytes in clusters multifocally scattered throughout the testicular tissue. There was an age-dependent change in the morphological appearance of the intersex gonads. In whitefish younger than $800 \mathrm{dph}$, most intersex gonads appeared

Table 2. Coregonus lavaretus. Gonad deviation types and sex ratios of $17 \beta$-estradiol (E2) exposed whitefish in control, low dose (LD; $0.5 \mu \mathrm{g} \mathrm{E} 2 \mathrm{~kg}^{-1}$ fish d ${ }^{-1}$ ), and high dose (HD; $50 \mu \mathrm{g} \mathrm{E} 2 \mathrm{~kg}^{-1}$ fish d $\mathrm{d}^{-1}$ ) treatments stratified by sex (M: males, F: females, IS: intersex). Values shown are number of fish $(\mathrm{N})$, frequency $(f)$ and $95 \%$ CI. Juvenile fish, i.e. specimens with gonads that could not be assessed macroscopically as either male or female, are not included in this table. These comprised 11 ind. in the control group, 9 in the LD group and 5 in the HD group

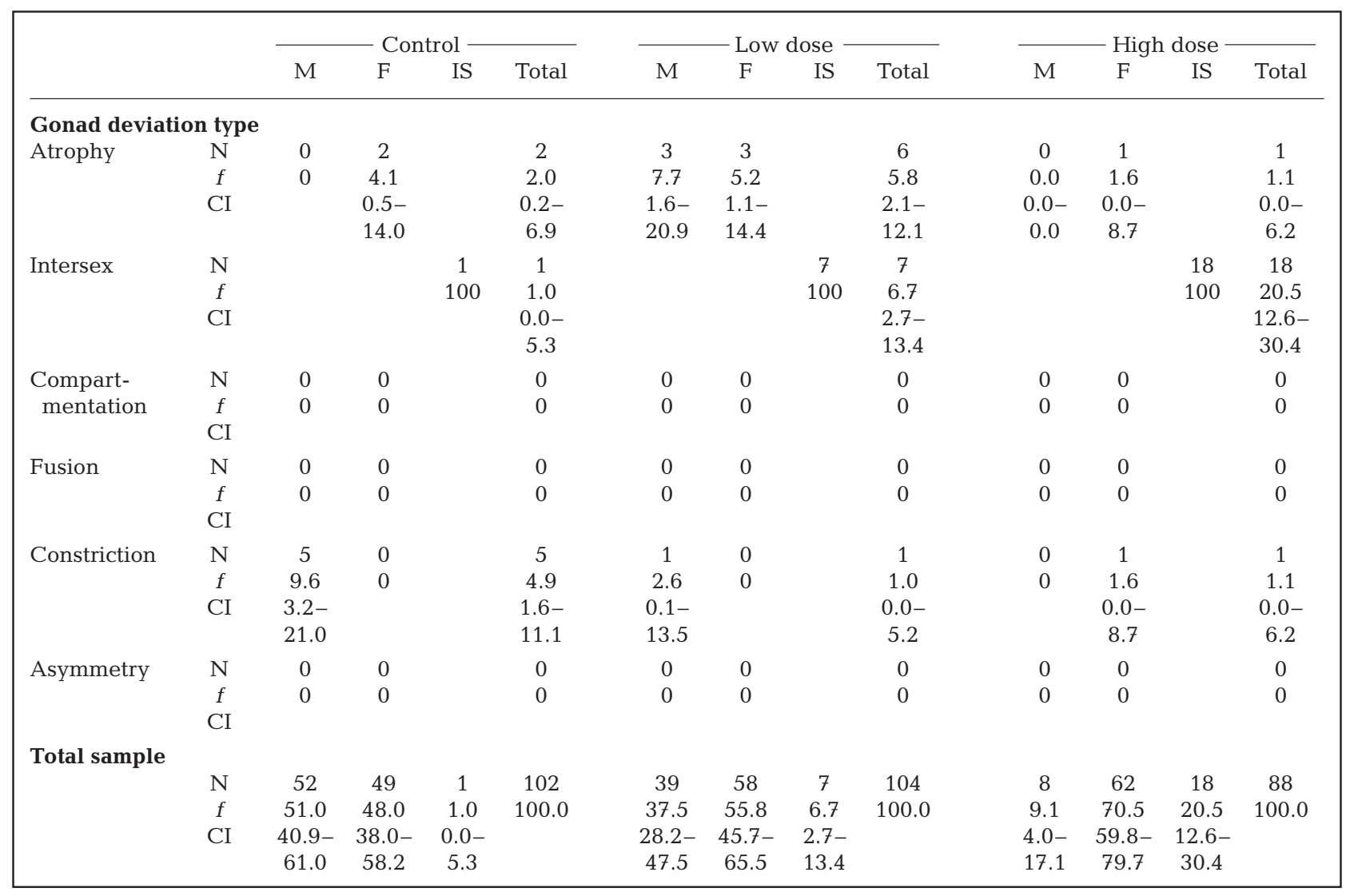


macroscopically as testis, and were also microscopically dominated by testicular structures, with only single oocytes dispersed in the tissue. In contrast, in fish older than $800 \mathrm{dph}$, the majority of the intersex gonads appeared macroscopically as ovaries and were microscopically dominated by an increased number of female germ cells, which now often appeared in clusters within the remaining male germ cells. Thus, 4 types of intersex morphology could be distinguished (Fig. 1): Type 1 showed mainly male tissue with normal lobular structure of the male segments and multifocally distributed, single oocytes. In Type 2, the testicular tissue with spermatogonia and/or spermatocytes as germ cells, showed an ovary-like lamellar structure, with a few oocytes being localized singly or in clusters. The male structures clearly dominated over the female ele- ments. In both Types 1 and 2, the vast majority of the oocytes were in the $\mathrm{PN}, \mathrm{BB}$ or CA stages, i.e. in early stages of oocyte maturation. The presence of single oocytes caused only minimal disruption to the male gonad tissue. When clusters of oocytes were present, they displaced sperm cysts within the lobule but did not change the overall testicular structure. In Type 3 intersex gonads, the ratio between male and female germ cells was shifted towards female germ cells. The gonad tissue showed a lamellar structure containing approximately equal proportions of intermingled clusters of either male or female germ cells. Usually, the male germ cell clusters contained 1 or 2 consecutive sperm cell maturation stages. The female germ cells were mostly in the BB and CA stages. Due to their increased number and size, the female germ cells
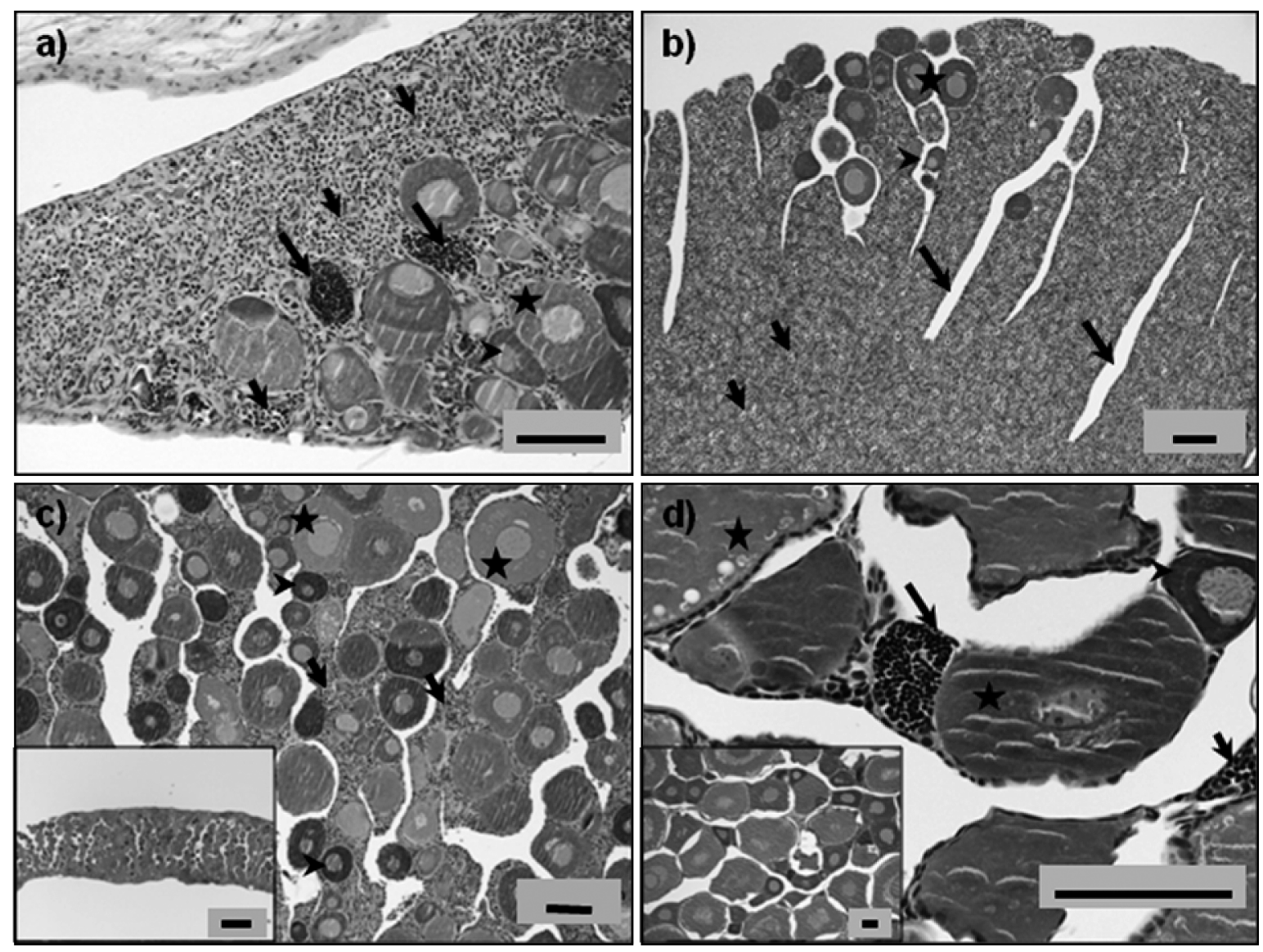

Fig. 1. Coregonus lavaretus. Various mosaic intersex gonads (Types 1 to 4 ) from the high dose group (50 $\mu$ g $17 \beta$-estradiol kg-1 fish $\mathrm{d}^{-1}$ ). Scale bars $=100 \mu \mathrm{m}$, except for inset in (c) where it is $500 \mu \mathrm{m}$. (a) Type 1: gonad section from a $469 \mathrm{~d}$ post hatch (dph) fish (20x). Balbiani body (arrowhead) and cortical alveolus stage oocytes (star) are multifocally embedded from the border towards the center of the strand. The testicular tissue shows normal male lobular structure containing spermatocytes (short arrows) and spermatids (long arrows). (b) Type 2: gonad section from a $469 \mathrm{dph}$ fish (10×). Note the ovary-like lamellar structure (long arrows) containing spermatocytes (short arrows) and the Balbiani body (arrowhead) and cortical alveolus stage oocytes (star) multifocally distributed at the border of the gonad strand. (c) Type 3: gonad section from a $960 \mathrm{dph}$ fish (10×). The lamellar structured strand (inset; $2.5 \times$ ) contains mostly Balbiani body stage (arrowheads) and cortical alveolus stage oocytes (stars) that are surrounded by multifocal confluent clusters of spermatogonia and spermatocytes (both short arrows). (d) Type 4: gonad section from a 960 dph fish (40x). Located between Balbiani body (arrowhead) and cortical alveolus stage oocytes (stars) are multifocally distributed nests containing spermatocytes (short arrow) and spermatids (long arrow). The inset shows an overview (10×) of the gonad section 
could locally displace the male cells within the gonad. Finally in Type 4, female germ cells occupied most parts of the gonad strand, with little space remaining for male tissue. Type 4 female germ cells were in the $\mathrm{PN}, \mathrm{BB}$ or CA stages, but some were in the VO stage. In male parts, mainly spermatocytes and spermatids occurred. In the HD group, an increase in both intersex prevalence and intensity with exposure time was revealed (Fig. 2). At 191 dph, intersex frequency in HD fish was $20 \%$ and increased to $30.6 \%$ at the end of exposure (960 dph). In the LD fish, intersex prevalence was $16.7 \%$ at $191 \mathrm{dph}$ and declined to $6.7 \%$ at $960 \mathrm{dph}$. In control fish, intersex was detected in only 1 fish at $469 \mathrm{dph}$ (prevalence of 1.4\%) (Fig. 2). The increasing intersex intensity was characterized by a shift from intersex Type 1 to intersex Type 4 (Fig. 2). Comparing the macroscopic appearance of the gonads that were microscopically classified as intersex, the exposure time dependent feminization was also clearly distinguishable. At $469 \mathrm{dph}, 100 \%$ of the microscopic intersex were macroscopically assessed as testis, while $72.7 \%$ were macroscopic ovaries at 960 dph (Table 3).

\section{Effects on sex ratio, condition indices, gonad maturation status, histopathology and VTG mRNA expression of whitefish}

In addition to the development of intersex gonads, a number of other parameters of whitefish responded to the chronic E2 treatments: (1) sex ratio, (2) CF, (3) GSI and gonad maturation status, (4) histopathology of liver, heart, kidney and gonads, and (5) hepatic VTG mRNA expression.

(1) Long-term exposure to E2 resulted in a dosedependent shift of the sex ratio towards females. While $48 \%$ were females in the control group, the percentage of fish with female gonads increased to $55.8 \%$ in the LD group and $70.5 \%$ in the HD group (Table 2). Control and LD groups did not significantly differ $(p>0.05)$ but both groups differed significantly from the HD group (Fisher's exact test; $\mathrm{p}<0.05 ; \mathrm{n}_{\mathrm{C}}=102 ; \mathrm{n}_{\mathrm{LD}}=104$; $\left.\mathrm{n}_{\mathrm{HD}}=88\right)$.

(2) Both males and females of the control (males: $1.3 \pm$ 0.0 [median $\pm \mathrm{SE}$ ]; females: $1.3 \pm 0.1$ ) and LD (males: $1.3 \pm 0.0$; females: $1.3 \pm 0.0$ ) treatments had significantly higher CIs than fish of the HD group (males: $1.1 \pm 0.1$; females: $1.1 \pm 0.0$ ) (Kruskal-Wallis multiple comparison $Z$-value test; $\mathrm{p}<0.05$; males: $Z>1.9 ; \mathrm{n}_{\mathrm{C}}=8 ; \mathrm{n}_{\mathrm{LD}}=3$; $\mathrm{n}_{\mathrm{HD}}=1$; females: $Z>1.9 ; \mathrm{n}_{\mathrm{C}}=7 ; \mathrm{n}_{\mathrm{LD}}=5 ; \mathrm{n}_{\mathrm{HD}}=16$ ). No significant differences were found between fish of the control and the LD treatments ( $p>0.05)$.

(3) Females of the control $(3.9 \pm 1.1$ [median $\pm \mathrm{SE}])$ and LD (4.2 \pm 2.3$)$ groups had significantly higher GSI than females of the HD $(0.8 \pm 0.3)$ group (Kruskal-Wal-

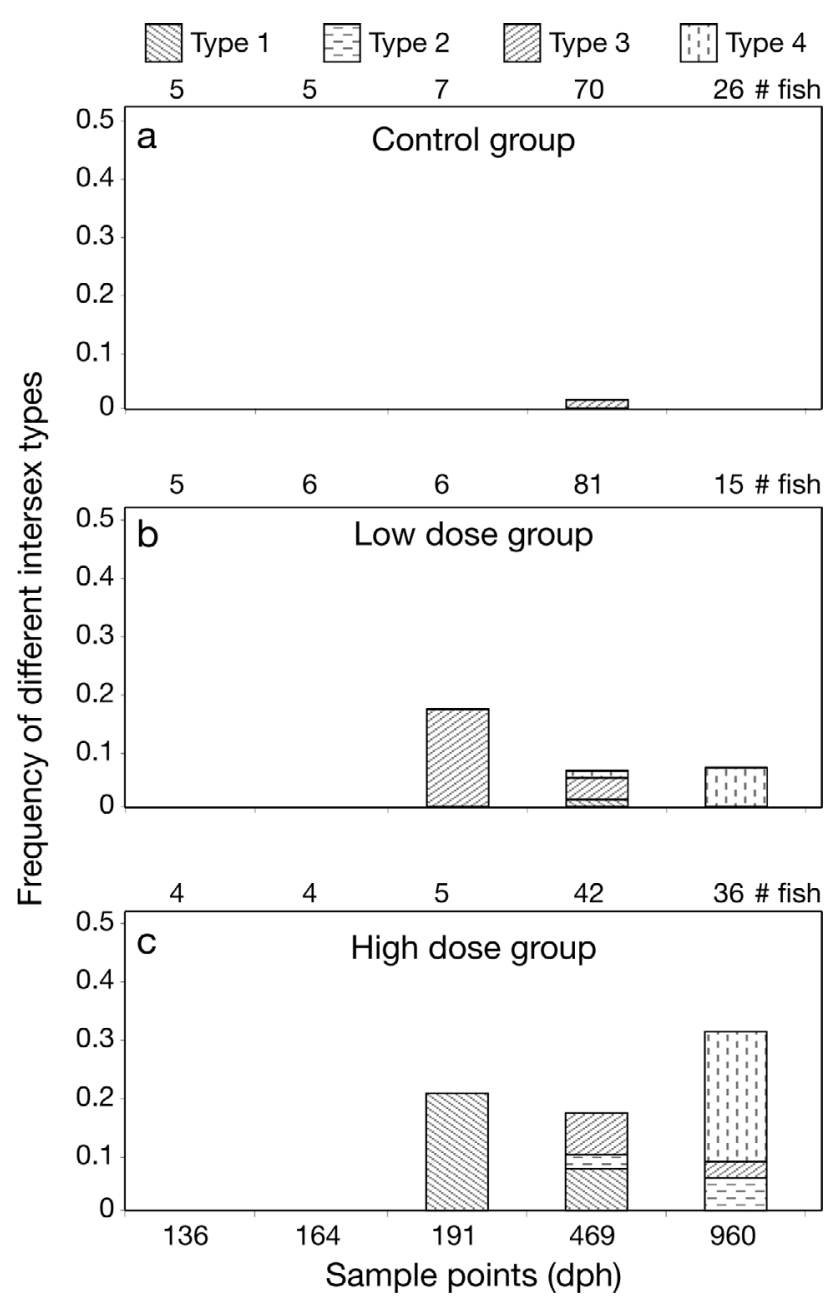

Fig. 2. Coregonus lavaretus. Frequency of different intersex types at the 5 consecutive sampling points. Intersex frequencies are given for (a) control group, (b) low dose group (0.5 $\mathrm{\mu g}$ $17 \beta$-estradiol $\mathrm{kg}^{-1}$ fish $\mathrm{d}^{-1}$ ), and (c) high dose group (50 $\mathrm{\mu g}$ $17 \beta$-estradiol $\mathrm{kg}^{-1}$ fish $\mathrm{d}^{-1}$ ). Number of fish indicated on the top $x$-axis

lis multiple comparison $Z$-value test; $\mathrm{p}<0.05 ; Z>1.9$; $\left.\mathrm{n}_{\mathrm{C}}=7 ; \mathrm{n}_{\mathrm{LD}}=5 ; \mathrm{n}_{\mathrm{HD}}=16\right)$. The GSI of males from the control group $(0.7 \pm 0.4)$ tended to be higher than that of males in the HD group $(0.1 \pm 0.1)$, although the difference was not significant ( $p>0.05 ; Z=1.2$ ). A significant difference, however, was evident between the 2 E2 treatments, with LD males showing higher GSI $(2.1 \pm 0.8)$ than HD males $(0.1 \pm 0.1$, Kruskal-Wallis multiple comparison $Z$-value test; $\mathrm{p}<0.05 ; Z>1.9 ; \mathrm{n}_{\mathrm{C}}=$ $8 ; \mathrm{n}_{\mathrm{LD}}=3 ; \mathrm{n}_{\mathrm{HD}}=1$ ). The lower GSI of HD fish correlated with a delayed maturation status of the germ cells in both sexes (Fig. 3). At final sampling, after $838 \mathrm{~d}$ of exposure, ovaries of fish from the control and LD groups were characterized by the prominent presence of VO, while ovaries from fish of the HD group were dominated by early oocyte stages, like the BB and CA 
Table 3. Coregonus lavaretus. Intersex gonads from fish of the high dose treatment (50 $\mu \mathrm{g}$ 17ß-estradiol (E2) $\mathrm{kg}^{-1}$ fish $\mathrm{d}^{-1}$ ) classified by microscopy, and related to macroscopic appearance and age. Macroscopic assessment: M: males; F: females; IS: intersex; ?: macroscopically not distinguishable. Values shown are frequency in \% and number of fish $(\mathrm{N})$. dph: d post hatch

\begin{tabular}{|lccccc|}
\hline & \multirow{2}{*}{ Age (dph) } & \multicolumn{4}{c|}{ Macroscopic appearance } \\
\cline { 3 - 6 } & & $\mathrm{M}(\mathrm{N})$ & $\mathrm{F}(\mathrm{N})$ & IS (N) & $?(\mathrm{~N})$ \\
\hline Microscopically & 191 & $(0)$ & $(0)$ & $(0)$ & $100.0(1)$ \\
classified as IS & 469 & $100.0(7)$ & $(0)$ & $(0)$ & $(0)$ \\
& 960 & $18.2(2)$ & $72.7(8)$ & $(0)$ & $9.1(1)$ \\
\hline
\end{tabular}

or macrophages, or a mixture of these cells.

(5) Hepatic VTG mRNA levels were significantly induced in a dose-dependent manner by chronic E2 exposure (Tukey-Kramer multiple comparison test; $\mathrm{p}<0.05 ; \mathrm{n}_{\mathrm{C}}=21 ; \mathrm{n}_{\mathrm{LD}}=19 ; \mathrm{n}_{\mathrm{HD}}=23$; Fig. 5). Male fish in the control group had a median VTG mRNA value of 0.1 copy $(1000)^{-1}$ copies of 18 s RNA. In the LD and HD groups, the median values were $5.4(1000)^{-1}$ and $32798(1000)^{-1}$ stage, with the number of VOs being low (Fig. 3). Further, while males of the control and LD groups had spermatozoa in their testes $838 \mathrm{~d}$ after the start of exposure, no spermatozoa were present in testes of fish from the HD group. The latter were mainly composed of spermatocytes and spermatids, together with a small number of spermatogonia (Fig. 3).

(4) In HD fish, a multifocal, slight to moderate accumulation of homogenous eosinophilic material was seen in the cytoplasm of the hepatocytes, as well as in the intercellular and vascular spaces of the liver tissue, in the cavity and in the coronary vessels of the heart, and in the glomerular loops and Bowman's space of the kidney (Fig. 4). Moreover, kidneys of fish from the HD group showed a moderate to severe fibroblastic proliferation of the walls of the Bowman's capsule (sclerotic glomeruli) as well as of blood vessel walls, and a moderate to severe thickening (classical wire-loop appearance), together with partial rupture of the glomerular basement membranes and capsules. These histopathological alterations in the kidney are indicative of chronic glomerulonephritis. In the LD group, histopathological changes were less strongly expressed and less frequent; for instance, thickening of the glomerular basement membranes in the kidney was slight and occurred in only $3.8 \%$ of the fish. No accumulation of homogenous eosinophilic material was observed in the liver, heart and kidney of fish from the LD and control groups. Also in the gonads, pathological changes going beyond the alterations in germ cell differentiation as described above but affecting the somatic cells were present. In the HD group, $59 \%$ of the fish showed an interstitial accumulation of homogenous eosinophilic material as well as a proliferation of fibroblasts in the arterial walls. In the LD group, an accumulation of homogenous eosinophilic material was found in only $5 \%$ of the gonads and it was absent from the gonads of control fish. In all treatments, the gonads of a few fish showed areas with slight to moderate inflammation with comparable prevalences (control: 16.7\%; LD: $12.5 \%$; HD: $17.0 \%$ ); these areas contained either neutrophilic granulocytes, eosinophilic granular cells

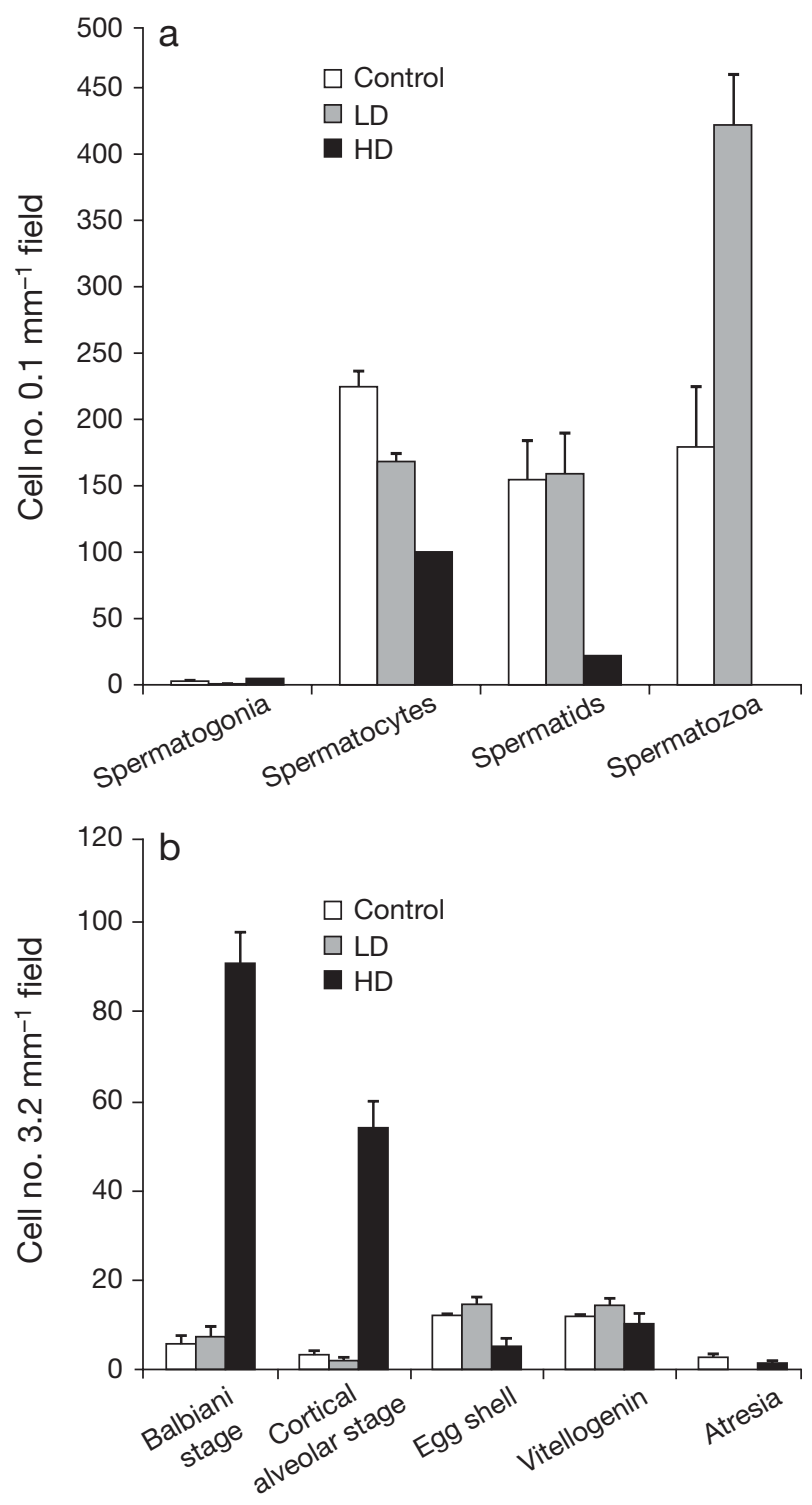

Fig. 3. Coregonus lavaretus. Germ cell numbers (means \pm SE) in males (a) and females (b) from the control, low dose (LD; $0.5 \mu \mathrm{g} 17 \beta$-estradiol $\mathrm{kg}^{-1}$ fish $\mathrm{d}^{-1}$ ) and high dose (HD; $50 \mu \mathrm{g}$ $17 \beta$-estradiol $\mathrm{kg}^{-1}$ fish $\mathrm{d}^{-1}$ ) treatments obtained by stereological analysis of the final samples (838 d of exposure) (see 'Materials and methods' for details of the counting procedure) 

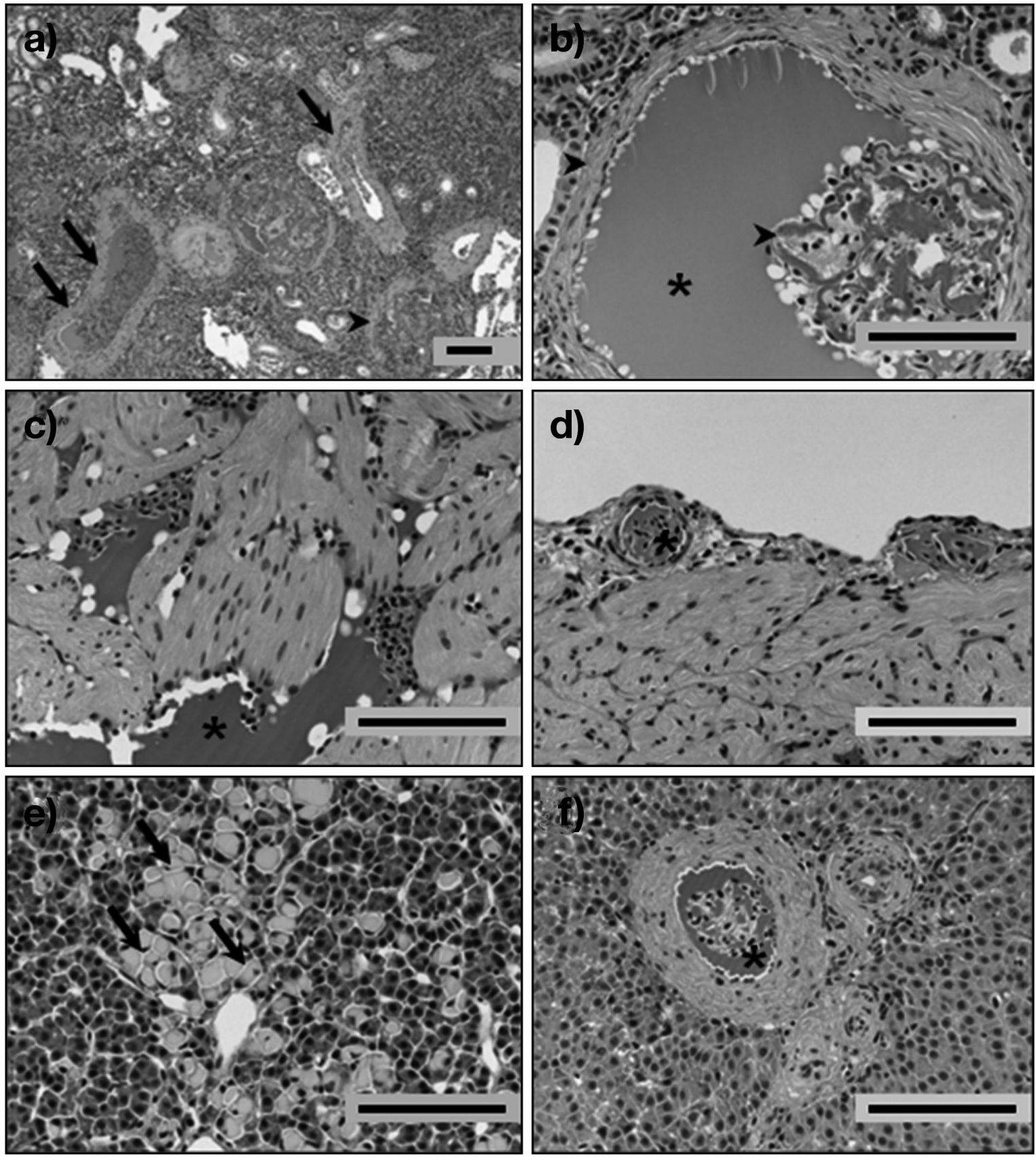

Fig. 4. Coregonus lavaretus. Organ sections from whitefish of the high dose group (50 $\mu \mathrm{g} 17 \beta$-estradiol kg $\mathrm{kg}^{-1}$ fish $\left.\mathrm{d}^{-1}\right)$. Scale bars $=$ $100 \mu \mathrm{m}$. (a) Kidney section (10×). Note fibroblastic proliferation of the Bowman's capsule walls (sclerotic glomeruli) (arrowhead) and vessel walls (arrows). (b) Kidney section $(40 \times)$, showing higher magnification of a glomerulus. Note thickening of the Bowman's capsule wall (arrowhead) and of the glomerular basement membranes (classical wire-loop appearance) with accumulation of homogenous eosinophilic material in the loops (arrowhead) and in the Bowman's space (asterisk). (c,d) Heart sections (40×): (c) accumulation of homogenous eosinophilic material in the heart cavity (asterisk) and (d) in the coronary vessels (asterisk). (e,f) Liver sections (40x): (e) vacuolar accumulation of homogenous eosinophilic material in the hepatocytes (arrows) and (f) intravascular deposit of eosinophilic material (asterisk) with marked thickening of cholangiar and vascular walls

copies of 18s RNA, respectively. In the LD group, hepatic VTG mRNA values of male fish were significantly increased over control values at Day 347 of E2 exposure, but did not differ from that in the control at final sampling (838 d of exposure) (Fig. 6). Hepatic VTG mRNA values in fish from the HD treatment group were significantly elevated over control values from the first sampling until the end of the experiment. There 
was no significant change in the induced VTG levels in the course of the experiment, from the first until the final sampling. In female control fish, the median VTG mRNA value was 0.4 copy $(1000)^{-1}$ copies of 18 s RNA. This value was only marginally higher than the median male VTG value, because $73.7 \%$ of female fish were in the previtellogenic stage. In the LD and HD groups, the level was $27.5(1000)^{-1}$ and $26696(1000)^{-1}$ copies of $18 \mathrm{~s}$ RNA, respectively. The time courses of the hepatic VTG mRNA induction in females under the 3 treatment groups were nearly congruent with that of the males. However, at the final sampling point, females of the control and the LD group had VTG values corresponding to that of females from the HD treatment group.

In all 3 treatment groups, the VTG levels of male fish with normal and deformed gonads (i.e. in our case atrophy and intersex) did not differ significantly (Tukey-Kramer multiple comparison test; $\mathrm{p}>0.05$ ).

\section{DISCUSSION}

In the present study, whitefish were chronically exposed to E2 from $122 \mathrm{dph}$ (first feeding) to $960 \mathrm{dph}$ (completion of gonad morphological differentiation and maturation), resulting in $838 \mathrm{~d}$ of exposure. While a number of long-term estrogenic exposure studies have been performed with fast-developing small laboratory species like the fathead minnow Pimephales promelas (Lange et al. 2001), zebrafish Danio rerio (Nash et al. 2004) and medaka Oryzias latipes (Seki et al. 2002), chronic estrogenic exposures have rarely been performed with long-lived, seasonally spawning

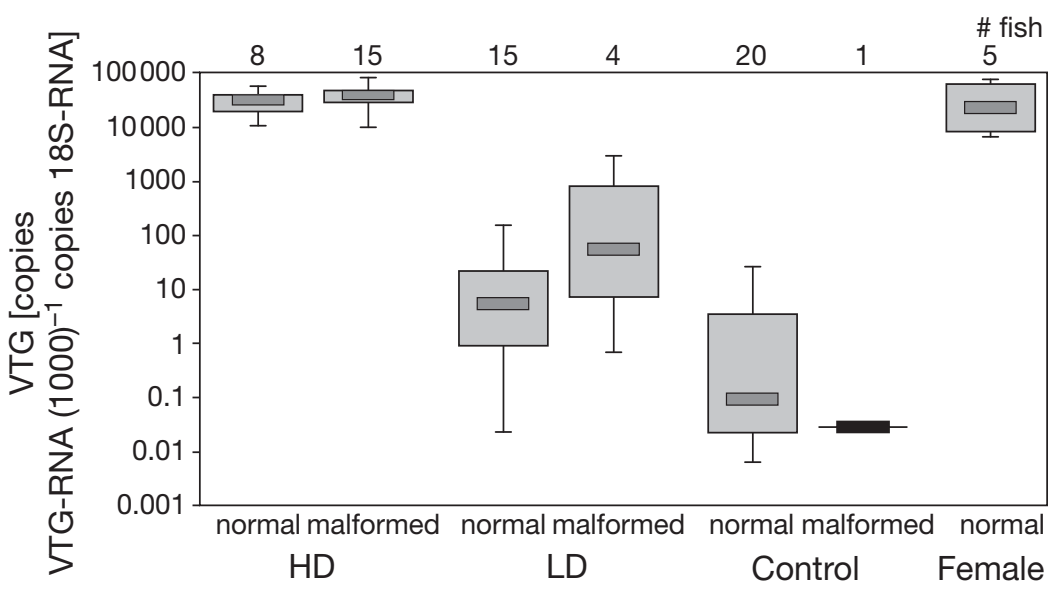

Fig. 5. Coregonus lavaretus. Hepatic vitellogenin (VTG) mRNA levels in males from the high dose (HD; $50 \mu \mathrm{g} 17 \beta$-estradiol $\mathrm{kg}^{-1}$ fish $\mathrm{d}^{-1}$ ), low dose (LD; $0.5 \mu \mathrm{g}$ $17 \beta$-estradiol $\mathrm{kg}^{-1}$ fish $\mathrm{d}^{-1}$ ) and control treatments, with normal and abnormal (atrophic and intersex) gonads. As a reference, the VTG values of females from the control group of the final sampling (838 $\mathrm{d}$ of exposure) are presented at the rightmost position. Values shown are median (thick black bar), 25th to 75th percentiles (grey box), and minimum-maximum (whiskers). Number of fish indicated on the top $x$-axis fish species. Rodgers-Gray et al. (2001) exposed roach Rutilus rutilus at 50 to $200 \mathrm{dph}$ (germ cell differentiation incomplete in some fish, presumptive males) to a graded concentration of effluents from sewage treatment plants. Liney et al. (2006) used a similar exposure scenario with roach from fertilization to $300 \mathrm{dph}$ (completed sexual differentiation). In both studies, estrogen exposed males developed feminized reproductive ducts, but no effects on germ cell differentiation were reported. Further, in whole-lake experiments, pearl dace Margariscus margarita (Palace et al. 2006) and fathead minnow P. promelas (Kidd et al. 2007) were chronically exposed to $17 \alpha$-ethynylestradiol (EE2) that resulted in the manifestation of intersex gonads and altered oogenesis. The rare use of long-lived wild fish species in prolonged exposure experiments may be related to problems associated with long-term rearing under laboratory conditions.

E2 exposure of developing whitefish resulted in physiological and pathological alterations as reported in other fish species exposed to estrogen-active compounds. Typical estrogen-dependent effects were clearly expressed in the HD group, but weak to absent in the LD group. Hepatic VTG mRNA levels showed a significant and concentration-dependent induction response to E2 exposure. This finding confirms that the dietary E2 administration as used in the present study was effective. VTG induction is a well-established biomarker response of fish to estrogenic exposure (Sumpter \& Jobling 1995). Advantages of the VTG biomarker are that the induction response, which is mediated through the estrogen receptor, is sensitive, specific and rapid (Arukwe \& Goksoyr 2003). At sampling 4 (347 d of exposure), VTG mRNA levels of male fish from the LD group were significantly higher than that in the control group, although the difference was no longer significant at the final sampling (838 d of exposure) since VTG levels in control fish clearly increased at 347 to $838 \mathrm{~d}$ of exposure. This observation suggests that the LD treatment induced a precocious VTG expression in male fish. Low levels of VTG expression, both of VTG protein in the plasma and VTG mRNA in the liver, in control males have been reported for several fish species and appears to be a normal background situation (Navas \& Segner 2006). Females from the control group showed pronounced hepatic VTG mRNA expression at termination of the experiment, reflecting their state of ovarian maturity. Hepatic VTG expression levels in females from the LD and HD groups did not differ significantly 


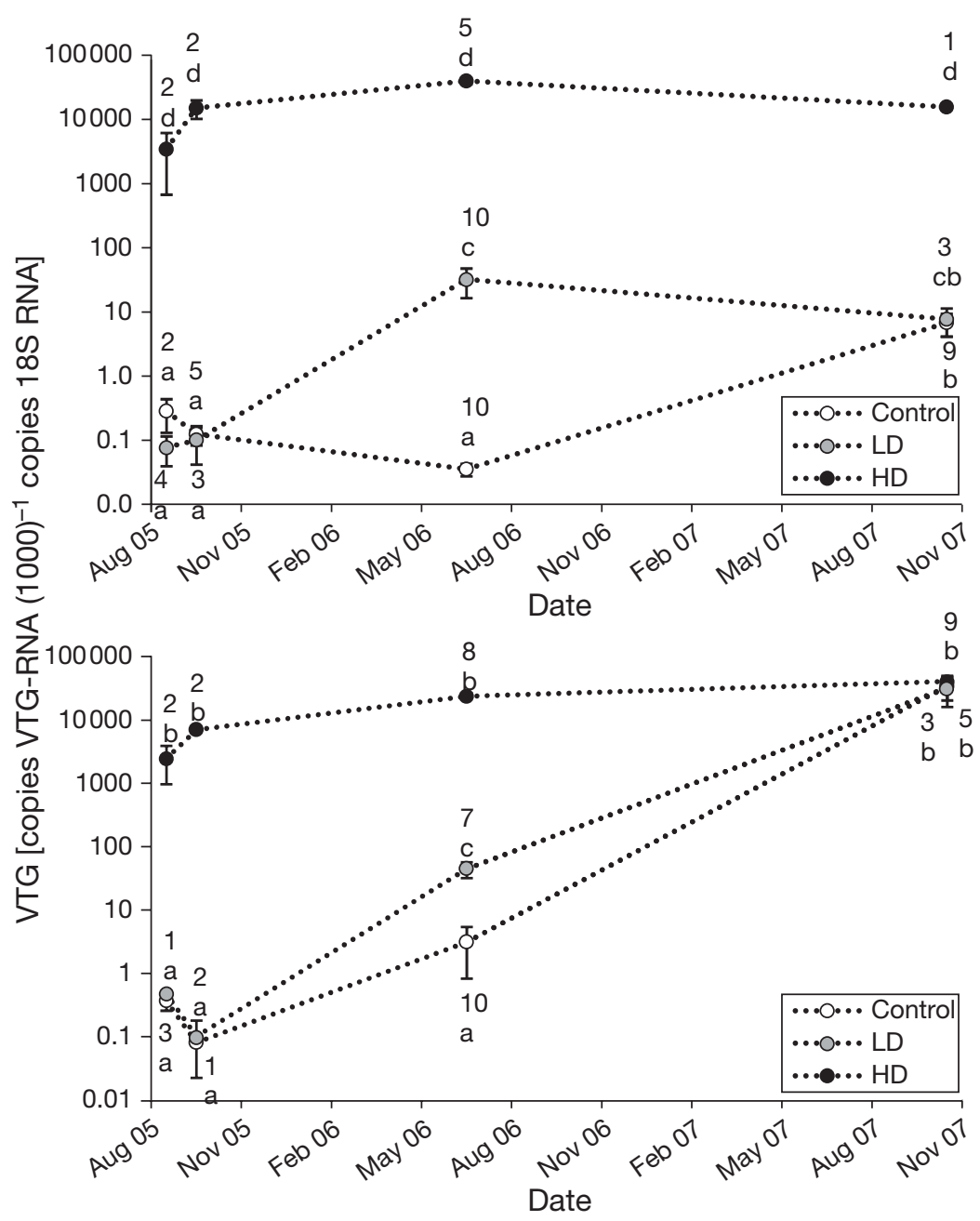

Fig. 6. Coregonus lavaretus. Hepatic vitellogenin (VTG) mRNA levels (means \pm $\mathrm{SE}$ ) in male (upper panel) and female (lower panel) whitefish from the high dose (HD; $50 \mu \mathrm{g} 17 \beta$-estradiol $\mathrm{kg}^{-1}$ fish $\mathrm{d}^{-1}$ ), low dose (LD; $0.5 \mu \mathrm{g} 17 \beta$-estradiol $\mathrm{kg}^{-1}$ fish $\mathrm{d}^{-1}$ ) and control treatments at the different samplings, except for the first sampling (14 d of exposure) due to insufficient amount of liver tissue. The number at every point indicates sample size. Values with different lower case letters are significantly different (GLM 2-way ANOVA with a Tukey-Kramer multiple comparison test; $\mathrm{p}<0.05$ )

from those of control females, i.e. the estrogenic exposure was not able to elevate hepatic VTG mRNA above levels that occur naturally in maturing females.

A concentration-dependent increase in the prevalence of intersex gonads and an exposure time-dependent enhancement of the intensity of intersex manifestation was found. In the HD treatment group, up to $21 \%$ of the fish displayed intersex gonads. The available literature on intersex induction in estrogen exposed fish points to some level of species specificity of this endpoint. In zebrafish Danio rerio, for instance, only very few intersex gonads were induced with EE2 exposure $\left(5 \mathrm{ng} \mathrm{l}^{-1}\right)$ over a whole life cycle (Nash et al. 2004, Fenske et al. 2005). In juvenile roach Rutilus rutilus, exposure to estrogenic effluents resulted in the feminization of the gonad duct, but not in the development of intersex in terms of mixed germ cells (Rodgers-Gray et al. 2001). A new observation of the present study is the relation between intersex morphology and duration of exposure. This is indicated on the one hand by the time-dependent shift in intersex intensity (from Type 1 to 4 ), and on the other hand by the observation that during early development (191 dph), microscopic intersex occurred mainly in gonads appearing macroscopically as testes, while later in development (>800 dph), microscopic intersex occurred predominantly in gonads appearing macroscopically as ovaries. We suppose that these fish are genotypic males that underwent an almost full sex reversal by developing ovaries, except for the presence of a few remnant male germ cells in the gonads. However, in the absence of a reliable method to determine the genotypic sex in whitefish, we cannot verify our assumption. Overall, however, intersex induction seems to be a dynamic process and to occur as an intermediate stage in development from the phenotypic male to the phenotypic female gonad (Gray \& Metcalfe 1997).

Fish in the HD group displayed major histopathological changes in the liver, heart, kidney and gonads. Histopathological lesions occurred after prolonged E2 exposure, e.g. rupture of the renal glomeruli. This was also observed by Folmar et al. (2001). These pathologies can be interpreted as a consequence of the VTG protein overload in the blood circulation by continuous E2 feeding and may lead to kidney function failure and heart activity effects. Prominent accumulation of homogenous eosinophilic material occurred in fish in this study. We interpreted the large amounts of homogenous eosinophilic material deposited in the organs mentioned above as VTG. In the summer flounder Paralichthys dentatus, the deposits were identified by immunohistochemistry as VTG (Folmar et al. 2001). Deposits of homogenous eosinophilic material were described, but not further identified, in summer flounder P. dentatus exposed to E2 (Zaroogian et al. 2001), in pearl dace Margariscus margarita exposed to synthetic estrogen (Palace et al. 2006) and in rare minnow Gobiocypris rarus exposed to ethynylestradiol and nonylphenol (Zha et al. 2007). 
Male fish from the HD group had smaller GSI and less mature germ cells than fish from the other groups. These observations indicate that E2 in high doses reduces testis maturation and therefore also the GSI. These findings are in agreement with results obtained by Gimeno et al. (1998a, b) and Diniz et al. (2005). However, no differences in the GSI were found in roach Rutilus rutilus exposed to estrogen-active sewage treatment plant effluents (Rodgers-Gray et al. 2001). Fish in the control and LD treatment groups had significantly higher CIs than fish in the HD group. The CF of HD fish was significantly reduced due to both reduced weight and length. Growth of fish has been reported to respond very sensitively to estrogen exposure (Ashfield et al. 1998, Schäfers et al. 2007). The underlying mechanisms of this growth inhibitory effect of estrogen exposure may be a crosstalk between the estrogen and the growth hormone $(\mathrm{GH}) /$ insulin-like growth factor (IGF) systems. Indeed, there exists good evidence that estrogens are able to interfere with both the endocrine GH/IGF-I system, through suppression of GH-dependent IGF-I synthesis in the liver, and with the paracrine IGF-I system, through local IGF production in the gonads (Segner et al. 2006, Shved et al. 2007, Shved et al. 2008). Alternatively, the reduced weight increase may result from reduced energy allocation due to increased demands for E2 metabolism, or it might be indicative of a toxicological effect of the prolonged administration of exogenous E2.

The chronic E2 exposure resulted in a dose-dependent shift of the sex ratio towards females. Increased number of fish with phenotypically female gonads as a result of estrogen exposures during gonad development were also reported in other fish species (e.g. in the Japanese medaka Oryzias latipes, Gray \& Metcalfe 1997; in tilapia Oreochromis niloticus, Shved et al. 2008; and in the white sucker Catostomus commersonii, Vajda et al. 2008). In gonochorists such as whitefish, sex steroids act as organizers of sex differentiation during a sensitive window of gonad development (Yamamoto 1969, Devlin \& Nagahama 2002). It is this organizational role of sex steroids in gonad differentiation that makes the developing gonad sensitive to environmental endocrine-disrupting compounds and can switch genetic males into phenotypic females (Segner et al. 2006).

Of the Lake Thun-typical gonad malformations (i.e. compartmentations, fusions, aplasia/atrophy, intersex) atrophic gonads were present in 1 and $6 \%$ of fish from the HD and LD treatments, respectively, showing no concentration dependence to the E2 exposure. Compartmentations and fusions did not occur at all in fish of the E2 exposure experiment. This is in clear contrast to the findings of Bernet et al. (2004) in whitefish from Lake Thun where values between $5 \%$ (fusions) to $11 \%$ (compartmentations) were recorded. The only excep- tion with a clear concentration dependence was the formation of microscopic intersex gonads, whereby the prevalence was significantly higher $(20.5 \%)$ in the laboratory E2 experiment than in the lake $(1.1 \%$ on average, D. Bernet unpubl.). These findings make it highly unlikely that the typical gonad malformations in whitefish from Lake Thun are a consequence of exposure to estrogenic active compounds. Likewise, there is no evidence that the gonad malformations are genetically determined. If the gonad malformations would be genetically fixed, our experimental fish which were reared in a non-Lake Thun environment should still have expressed the gonad alterations. Of the parental fish from Lake Thun that were used as gamete donors for the fish in this experiment, $12 \%$ of the males had testes with compartmentations and/or fusions (the mothers had all morphologically normal ovaries). These alterations, however, were not present in the offspring (fish of this experiment). However, data from this experiment do not allow definitive exclusion of genetics from the list of possible causes for the gonad alterations. If the gonad alterations would result from a genetic predisposition, we would not expect to see the gonad alterations in our experimental fish reared in a non-Lake Thun environment, as long as the relevant environmental factors were not present during the experiment. However, our experiment was not designed to evaluate the importance of genetic factors (but to examine the role of environmental EDC exposure); thus, further experiments are needed to definitely rule out genetic factors as a cause of the gonad alterations.

In conclusion, long-term exposure of European whitefish Coregonus lavaretus to E2 during the whole period from gonad differentiation until gonad maturity resulted in typical estrogen-disruptive effects like (1) elevated hepatic VTG mRNA levels, (2) formation of microscopic intersex gonads, (3) accumulation of VTG in the liver, heart, kidney and gonads, (4) both a reduced $\mathrm{CF}$ and gonad growth with delayed maturation of the germ cells, and (5) concentration-dependent shift in the sex ratio towards females. Importantly, estrogen exposure during gonad development did not induce the gonad morphological features that are described to be characteristic for Lake Thun coregonids. Therefore, we conclude that a causative role of estrogenic compounds in the morphological gonad alterations of Lake Thun whitefish is rather unlikely. This, however, does not exclude a possible role of the Lake Thun environment in the induction of the malformations. Further studies are ongoing to examine the role of Lake Thun water, food, and sediment in causing this enigmatic biological phenomenon.

Acknowledgements. This study was funded by the NRP 50 'Endocrine Disruptors: Relevance to Humans, Animals and 
Ecosystems'. We thank B. Mueller for her help in maintaining the fish, A. Liedke for the estrogenic activity test (YES-assay) and R. Schönenberger for the estrogen concentration analyses (HPLC) of the fish feed.

\section{LITERATURE CITED}

Arukwe A, Goksoyr A (2003) Eggshell and egg yolk proteins in fish: hepatic proteins for the next generation: oogenetic, population, and evolutionary implications of endocrine disruption. Comp Hepatol 2:4

> Ashfield LA, Pottinger TG, Sumpter JP (1998) Exposure of female juvenile rainbow trout to alkylphenolic compounds results in modifications to growth and ovosomatic index. Environ Toxicol Chem 17:679-686

Baroiller JF, Guiguen Y, Fostier A (1999) Endocrine and environmental aspects of sex differentiation in fish. Cell Mol Life Sci 55:910-931

Bernet D, Wahli T, Kueng C, Segner H (2004) Frequent and unexplained gonadal abnormalities in whitefish (central alpine Coregonus sp.) from an alpine oligotrophic lake in Switzerland. Dis Aquat Org 61:137-148

Bittner D, Bernet D, Wahli T, Segner H, Küng C, Largaider CR (in press) How normal is abnormal? Discriminating between deformations and natural variation in gonad morphology of European whitefish Coregonus lavaretus from Swiss lakes. J Fish Biol

Blazer VS (2002) Histopathological assessment of gonadal tissue in wild fishes. Fish Physiol Biochem 26:85-101

Burki R, Vermeirssen ELM, Korner O, Joris C, BurkhardtHolm P, Segner H (2006) Assessment of estrogenic exposure in brown trout Salmo trutta in a Swiss midland river: integrated analysis of passive samplers, wild and caged fish, and vitellogenin mRNA and protein. Environ Toxicol Chem 25:2077-2086

> Devlin RH, Nagahama Y (2002) Sex determination and sex differentiation in fish: an overview of genetic, physiological, and environmental influences. Aquaculture 208: 191-364

Diniz MS, Peres I, Magalhaes-Antoine I, Falla J, Pihan JC (2005) Estrogenic effects in crucian carp Carassius carassius exposed to treated sewage effluent. Ecotoxicol Environ Saf 62:427-435

> Fenske M, Maack G, Schafers C, Segner H (2005) An environmentally relevant concentration of estrogen induces arrest of male gonad development in zebrafish Danio rerio. Environ Toxicol Chem 24:1088-1098

Folmar LC, Gardner GR, Schreibman MP, Magliulo-Cepriano L and others (2001) Vitellogenin-induced pathology in male summer flounder Paralichthys dentatus. Aquat Toxicol 51:431-441

Garcia-Reyero N, Raldua D, Quiros L, Llaveria G and others (2004) Use of vitellogenin mRNA as a biomarker for endocrine disruption in feral and cultured fish. Anal Bioanal Chem 378:670-675

Gimeno S, Komen H, Gerritsen AGM, Bowmer T (1998a) Feminisation of young males of the common carp Cyprinus carpio exposed to 4-tert-pentylphenol during sexual differentiation. Aquat Toxicol 43:77-92

> Gimeno S, Komen H, Jobling S, Sumpter J, Bowmer T (1998b) Demasculinisation of sexually mature male common carp Cyprinus carpio exposed to 4-tert-pentylphenol during spermatogenesis. Aquat Toxicol 43:93-109

Gray MA, Metcalfe CD (1997) Induction of testis-ova in Japanese medaka Oryzias latipes exposed to p-nonylphenol. Environ Toxicol Chem 16:1082-1086
Gray MA, Niimi AJ, Metcalfe CD (1999) Factors affecting the development of testis-ova in medaka Oryzias latipes exposed to octylphenol. Environ Toxicol Chem 18: 1835-1842

> Guerrero RD (1975) Use of androgens for the production of all-male Tilapia aurea (Steindachner). Trans Am Fish Soc 104:342-348

Jobling S, Tyler CR (2003) Endocrine disruption, parasites and pollutants in wild freshwater fish. Parasitology 126: S103-S108

Jobling S, Nolan M, Tyler CR, Brighty G, Sumpter JP (1998) Widespread sexual disruption in wild fish. Environ Sci Technol 32:2498-2506

Kidd KA, Blanchfield PJ, Mills KH, Palace VP, Evans RE, Lazorchak JM, Flick RW (2007) Collapse of a fish population after exposure to a synthetic estrogen. Proc Natl Acad Sci USA 104:8897-8901

Kime DE (1995) The effects of pollution on reproduction in fish. Rev Fish Biol Fish 5:52-96

Kinnison MT, Unwin MJ, Jara F (2000) Macroscopic intersexuality in salmonid fishes. N Z J Mar Freshw Res 34: $125-134$

> Lange R, Hutchinson TH, Croudace CP, Siegmund F and others (2001) Effects of the synthetic estrogen $17 \alpha-$ ethinylestradiol on the life-cycle of the fathead minnow Pimephales promelas. Environ Toxicol Chem 20: 1216-1227

Liney KE, Hagger JA, Tyler CR, Depledge MH, Galloway TS, Jobling S (2006) Health effects in fish of long-term exposure to effluents from wastewater treatment works. Environ Health Perspect 114:81-89

Matozzo V, Gagné F, Marin MG, Ricciardi F, Blaise C (2008) Vitellogenin as a biomarker of exposure to estrogenic compounds in aquatic invertebrates: a review. Environ Int 34:531-545

> Mikaelian I, de Lafontaine Y, Harshbarger JC, Lee LLJ, Martineau D (2002) Health of lake whitefish (Coregonus clupeaformis) with elevated tissue levels of environmental contaminants. Environ Toxicol Chem 21:532-541

> Nash JP, Kime DE, Van der Ven LTM, Wester PW and others (2004) Long-term exposure to environmental concentrations of the pharmaceutical ethynylestradiol causes reproductive failure in fish. Environ Health Perspect 112: 1725-1733

Navas JM, Segner H (2006) Vitellogenin synthesis in primary cultures of fish liver cells as endpoint for in vitro screening of the (anti) estrogenic activity of chemical substances. Aquat Toxicol 80:1-22

> Nolan M, Jobling S, Brighty G, Sumpter JP, Tyler CR (2001) A histological description of intersexuality in the roach. J Fish Biol 58:160-176

Palace VP, Wautier KG, Evans RE, Blanchfield PJ and others (2006) Biochemical and histopathological effects in pearl dace Margariscus margarita chronically exposed to a synthetic estrogen in a whole lake experiment. Environ Toxicol Chem 25:1114-1125

Patino R, Redding J (2000) Microscopical functional anatomy: reproductive systems. In: Ostrander GK (ed) Handbook of experimental animals. The Laboratory Fish Academic Press, London, p 489-500

Patino R, Davis KB, Schoore JE, Uguz C and others (1996) Sex differentiation of channel catfish gonads: normal development and effects of temperature. J Exp Zool 276: 209-218

> Rodgers-Gray TP, Jobling S, Kelly C, Morris S and others (2001) Exposure of juvenile roach (Rutilus rutilus) to treated sewage effluent induces dose-dependent and persistent disruption in gonadal duct development. Environ 
Sci Technol 35:462-470

Schäfers C, Teigeler M, Wenzel A, Maack G, Fenske M, Segner $\mathrm{H}$ (2007) Concentration- and time-dependent effects of the synthetic estrogen, 17ß-ethinylestradiol, on reproductive capabilities of the zebrafish Danio rerio. J Toxicol Environ Health A 70:768-779

Segner H, Caroll K, Fenske M, Janssen CR and others (2003) Identification of endocrine-disrupting effects in aquatic vertebrates and invertebrates: report from the European IDEA project. Ecotoxicol Environ Saf 54:302-314

Segner H, Eppler E, Reinecke M (2006) The impact of environmental hormonally active substances on the endocrine and immune systems of fish. In: Reinecke M, Zaccone G, Kapoor BG (eds) Fish endocrinology, Vol 2. Science Publishers, Enfield, NH, p 809-865

Seki M, Yokota H, Matsubara H, Tsuruda Y, Maeda N, Tadokoro H, Kobayashi K (2002) Effect of ethinylestradiol on the reproduction and induction of vitellogenin and testis-ova in medaka Oryzias latipes. Environ Toxicol Chem 21:1692-1698

Shved N, Berishvili G, D'Cotta H, Baroiller JF, Segner H, Eppler E, Reinecke M (2007) Ethinylestradiol differentially interferes with IGF-I in liver and extrahepatic sites during development of male and female bony fish. J Endocrinol 195:513-523

Shved N, Berishvili G, Baroiller JF, Segner H, Reinecke M (2008) Environmentally relevant concentrations of $17 \alpha-$ ethinylestradiol (EE2) interfere with the growth hormone (GH)/insulin-like growth factor (IGF)-I system in developing bony fish. Toxicol Sci 106:93-102

Sumpter JP, Jobling S (1995) Vitellogenesis as a biomarker for

Editorial responsibility: Thomas Brambeck,

Heidelberg, Germany estrogenic contamination of the aquatic environment. Environ Health Perspect 103:173-178

Sumpter JP, Johnson AC (2005) Lessons from endocrine disruption and their application to other issues concerning trace organics in the aquatic environment. Environ Sci Technol 39:4321-4332

Vajda AM, Barber LB, Gray JL, Lopez EM, Woodling JD, Norris DO (2008) Reproductive disruption in fish downstream from an estrogenic wastewater effluent. Environ Sci Technol 42:3407-3414

> van Aerle R, Runnalls TJ, Tyler CR (2004) Ontogeny of gonadal sex development relative to growth in fathead minnow. J Fish Biol 64:355-369

> Wiklund T, Lounasheimo L, Lom J, Bylund G (1996) Gonadal impairment in roach Rutilus rutilus from Finnish coastal areas of the northern Baltic sea. Dis Aquat Org 26: 163-171

Yamamoto T (1969) Sex differentiation. In: Hoar WS, Randall DJ (eds) Fish physiology, Vol 3. Academic Press, New York, p 117-175

Zaroogian G, Gardner G, Horowitz DB, Gutjahr-Gobell R, Haebler R, Mills L (2001) Effect of 17 $\beta$-estradiol, $o, p^{\prime}$-DDT, octylphenol and $p, p^{\prime}$-DDE on gonadal development and liver and kidney pathology in juvenile male summer flounder Paralichthys dentatus. Aquat Toxicol 54:101-112

Zha J, Wang Z, Wang N, Ingersoll C (2007) Histological alternation and vitellogenin induction in adult rare minnow Gobiocypris rarus after exposure to ethynylestradiol and nonylphenol. Chemosphere 66:488-495

Submitted: October 6, 2008; Accepted: January 9, 2009 Proofs received from author(s): March 2, 2009 